\title{
ОСОБЛИВОСТІ АНТРОПОГЕННОГО НАВАНТАЖЕННЯ НА ЛАНДШАФТИ ВОЛИНСЬКОГО ПОЛІССЯ В КОНТЕКСТІ ГЕОЕКОЛОГІЧНОЇ ДІАГНОСТИКИ ОЗЕРНО-БАСЕЙНОВИХ СИСТЕМ
}

\section{Зубкович I. B., Мартинюк В. O.}

\section{ВСТУП}

Однією 3 найбільш заозерених фізико-географічних областей України $є$ Волинське Полісся, яке вирізняється розгалуженою гідрографічною сіткою, мальовничими ландшафтами, значною кількістю природно-заповідних територій. 3 метою охорони раритетних ландшафтних комплексів i унікальних природних аквальних комплексів (далі - ПАК) озер тут створені Рівненський та Черемський природні заповідники, національні природні парки Шацький, Прип'ятьСтохід, Нобельський і низка інших природоохоронних територій загальнонаціонального рівня та місцевого значення. Водночас ландшафти регіону протягом останніх 150 років зазнали суттєвих антропогенних змін, що пов'язані з осушувальною меліорацією, будівництвом гідротехнічних споруд, аграрно-промисловим і селитебним освоєнням територій, видобутком корисних копалин тощо. Значні території поліських ландшафтів сьогодні є радіоактивно забрудненими внаслідок катастрофи на Чорнобильській атомної електростанції (далі - АЕС) (1986р.), а деякі природно-заповідні комплекси розташовані в зоні радіаційного ризику (30-тикелометрова зона) діючої Рівненської АЕС.

У зв'язку зі зростанням антропогенного навантаження на ландшафти Волинського Полісся та глобальними змінами клімату актуалізуються питання оцінки геоекологічного стану локальних парагенетичних систем, зокрема озерно-басейнових систем (далі ОБС), які сформувалися в межах конкретних фізико-географічних районів. Такі пошуки важливі у зв'язку з розробленням стратегії збалансованого природокористування нових адміністративних територій - об'єднаних територіальних громад (далі - ОТГ), де ОБС мають посісти важливе місце як природно-господарські системи (далі ПГС).

Ландшафти Волинського Полісся на початку XX ст. досліджував П.А. Тутковський, у післявоєнний час - учені Київського (О. Маринич та ін.) та Львівського (К. Геренчук, П. Климович, С. Кукурудза, Н. Орел та ін.) університетів. Що стосується сучасних 
ландшафтознавчих пошуків Волинського Полісся, які спрямовані на пізнання структури природних територіальних і аквальних комплексів та їх модифікацій, то вони проводяться Л. Ільїним ${ }^{1}$, О. Ільїною та ін. ${ }^{2}$, I. Койновою ${ }^{3}$, Л. Малишевою та ін. ${ }^{4}$, В. Мартинюком ${ }^{5}$, О. Міщенко ${ }^{6}$, Л. Сорокіною ${ }^{7}$ й іншими вченими. Формування i розвиток ОБС відбуваються під впливом як конкретних ландшафтів, так і геоекологічних процесів, що протікають у межах їхніх водозборів. Тому важлива оцінка геоекологічного стану ОБС для потреб збалансованого природокористування й управління цими ПГС.

Матеріалами дослідження послужили дані щодо кількості населення (станом на 1 січня 2018 р.) Головних управлінь статистики у Волинській і Рівненській областях, районних адміністрацій і ОТГ, які згруповувалися за населеними пунктами в межах кожного з фізикогеографічних районів (далі - ФГР). Для ідентифікації конфігурації поселень i здійснення оцінки площ населених пунктів використовувалися космознімки високої роздільної здатності із застосуванням програмного пакету ArcGIS 10.3. У методичному плані врахована методика Р. Ідрісової ${ }^{8}$ й О. Нечаї та демографічного навантаження на ландшафтні комплекси. Методикою з геоекологічної діагностики модельних ОБС слугували

${ }^{1}$ Ільїн Л. Лімнокомплекси Українського Полісся : монографія : у 2-х т. Т. 2 : Регіональні особливості та оптимізація. Луцьк : РВВ «Вежа» Волин. нац. ун-ту імені Лесі Українки, 2008. 400 с.

2 Ільїна О., Кукурудза С. Болотні геокомплекси Волині : монографія. Львів : Вид-й центр ЛНУ імені Івана Франка, 2009. 242 с.

Койнова I. Антропогенна трансформація ландшафтних систем західної частини Волинського Полісся : автореф. дис. ... канд. геогр. наук: 11.00.11. Львів, 1999. 19 с.

${ }^{4}$ Ландшафтно-екологічні дослідження у 30 -кілометровій зоні Рівненської АЕС : основні результати, досвід використання ГІС / Л. Малишева та ін. Украӥнський географічний журнал. 2003. № 1. С. 21-32.

Мартинюк В. Ландшафтометрична оцінка геокомплексів фізико-географічного району (на прикладі Волинського Полісся). Наукові записки Тернопільського державного педагогічного університету. Серія «Географія». 2016. № 2 (41). С. 65-72 ; Мартинюк В. Оцінка ландшафтної структури локальних територій Волинського Полісся для потреб збалансованого природокористування. Науковий вісник Херсонського держсного уіверситету. Серія «Географічні науки». 2017. Вип. 6. С. 152-159.

${ }^{6}$ Міщенко О. Ландшафти Волинської області. Наукові записки Тернопільського національного педагогічного університету імені Володимира Гнатюка. Серія «Географія». 2016. № 2. С. 72-77.

Сорокіна Л. ГІС-аналіз умов міграції техногенних забруднювачів в ландшафтах Волинського Полісся. Науковий вісник Волинського державного університету імені Лесі Українки. Серія «Географічні науки». 2007. № 11. Ч. ІІ. С. 100-104.

8 Идрисова Р. Комплексная оценка современного состояния ландшафтов Чеченской Республики. Вопросы современной науки и практики. Университет им. В.И. Вернадского. 2008. Т. 2. № 4 (14). С. 47-51.

${ }_{9}^{9}$ Ничая О. Сільські селитебні ландшафти Волинської області: сучасний стан та шляхи збалансованого розвитку : автореф. дис. ... канд. геогр. наук: 11.00.11. Луцьк, 2019. $20 \mathrm{c}$. 
наші розробки ${ }^{10}$, які грунтуються на багаторічному досвіді ландшафтно-лімнологічних досліджень Волинського Полісся. Алгоритм-схема пошуків наведено на рис. 1.

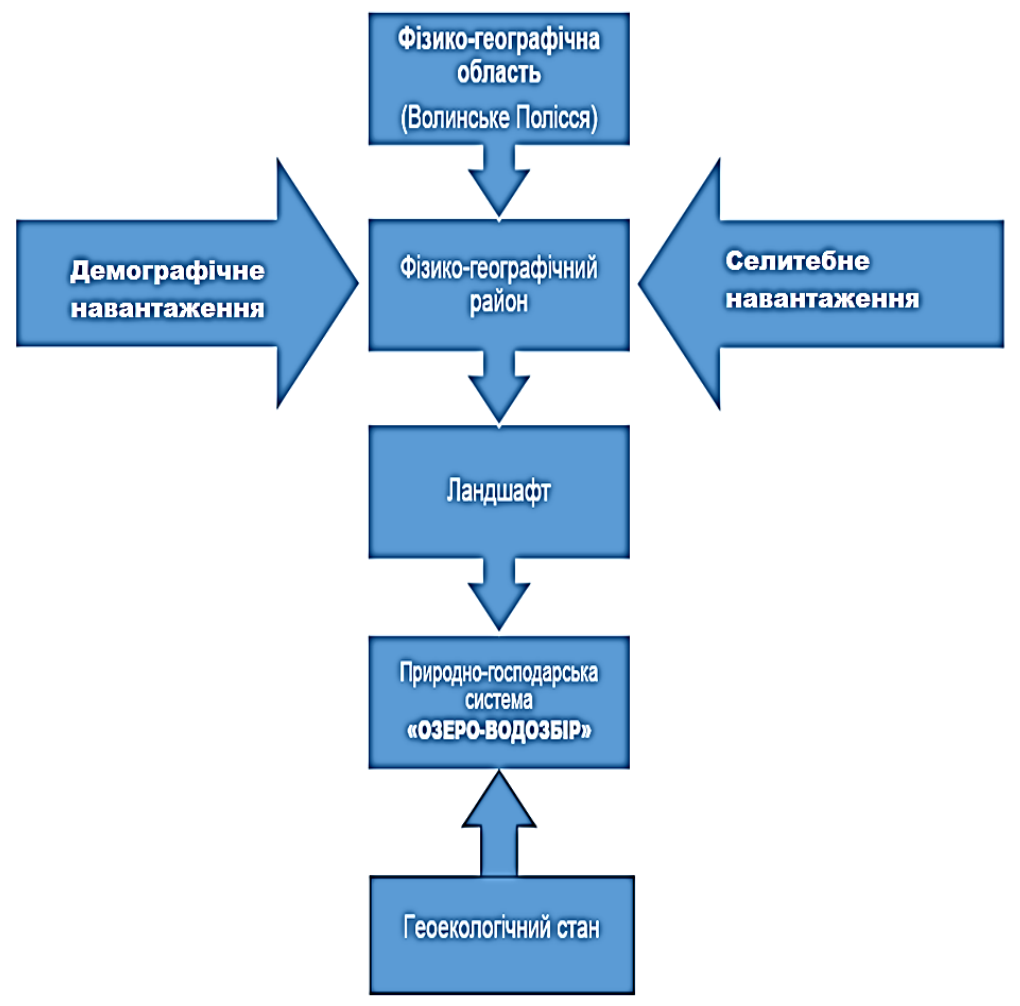

\section{Рис. 1. Схема дослідження антропогенного навантаження на ландшафти й озерно-басейнові системи}

10 Зубкович I., Мартинюк В., Андрійчук С. Оцінка геоекологічного стану басейнової системи озера Радожичі із застосуванням геоінформаційних технологій. Науковий вісник Східноєвропейського начіонального університету імені Лесі Українки. Серія «Географічні науки». 2019. № 9 (393). С. 27-36 ; Мартынюк В. Модель геоэкологического состояния озерно-бассейновой системы. Веснік Брэсикага уиніверсітэта. Серыя 5 «Хімія. Біялогія. Навукі аб зямлі». 2018. № 2. C. 108-116 ; Мартинюк В., Зубкович I. Ландшафтно-географічна модель екологічного паспорта басейнової системи озера Озерце (Волинське Полісся). Людина та довкілля. Проблеми неоекологї̈. 2017. № № 3-4. С. 29-39. 


\section{1. Особливості селитебного}

\section{та демографічного навантаження на ландшафти}

Площа фізико-географічної області Волинського Полісся, за оцінками В. Мартинюка ${ }^{11}$, становить 27 239,5 км², майже чверть $(24,11 \%)$ території Українського Полісся. У межах цього природного регіону із застосуванням програмного пакету ArcGIS 10.3 нами виокремлено й оцифровано площі 1072 населених пунктів (рис. 2).

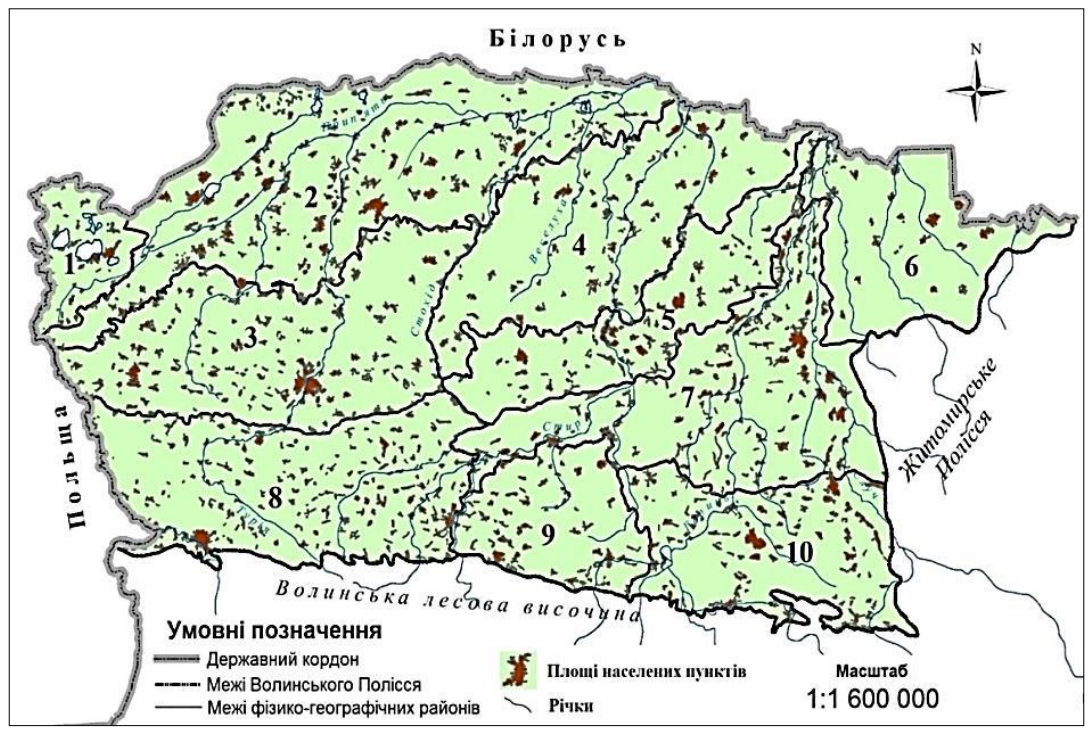

\section{Рис. 2. Розміщення населених пунктів у межах фізико-географічних районів Волинського Полісся}

\section{Умовні позначення:}

Підобласть Верхньоприп'ятського Полісся.

Фізико-географічні райони: 1. Шачький. 2. Верхньоприп'ятський.

3. Любомльсько-Ковельський. 4. Нижньостирський.

Підобласть Буго-Горинського Полісся.

Фізико-географічні райони: 5. Маневицько-Володимиреиький.

6. Льва-Горинський. 7. Колківсько-Сарненський. 8. Турійсько-Рожищенський.

9. Ківериівсько-Цуманський. 10. Костопільсько-Березнівський

11 Мартинюк В. Регіональне ландшафтно-гідрографічне ГІС-моделювання поверхневих вод Полісся. Прыроднае асяроддзе Палесся : асаблівасиі $i$ перспектывы развіщия : зборнік навуковых прац. Брэст : Альтернатива, 2018. Вып. 11. С. 70-73. 
Для оцінки селитебного та демографічного навантаження Волинського Полісся був обраний модельний Шацький ФГР, загальна площа якого становить 734,31 км² (рис. 3). До складу природного району війшло 34 населених пункти (4,6 населених пункти на $\left.1,0 \mathrm{kм}^{2}\right)$, iз них 25 належать до Шацького і 9 до Любомльського адміністративних районів. У даному ФГР, за нашими оцінками, мешкає 19656 осіб. У районному центрі смт Шацьк проживає 5,3 тис. осіб (табл. 1). У кількох населених пунктах мешкає понад 1,0 тис. осіб, зокрема: села Піща (1,2 тис. осіб), Мельники (1,2 тис. осіб), Світязь (1,8 тис. осіб), Пульмо (1,4 тис. осіб). Щільність населення на 1,0 км² становить 26,8 осіб.

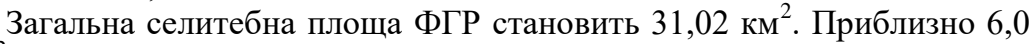
км$^{2}$ становить площа селитебної структури смт Шацьк. Серед інших населених пунктів ФГР, що мають площу селитебних земель понад 1,0 км $^{2}$, варто назвати села Перешпа $\left(3,1 \mathrm{kм}^{2}\right)$, Ростань $\left(1,2 \mathrm{kм}^{2}\right)$, Мельники $\left(1,8 \mathrm{\kappa м}^{2}\right)$, Світязь $\left(2,4 \mathrm{kм}^{2}\right)$, Пульмо $\left(1,2 \mathrm{kм}^{2}\right)$, Забужжя $\left(2,2 \mathrm{kм}^{2}\right)$, Столинські Смоляри $\left(1,4 \mathrm{~km}^{2}\right)$, Гуща $\left(1,2 \mathrm{~km}^{2}\right)$. Загальна частка селитебних земель у межах ФГР становить $4,22 \%$. Тісне розташування смт Шацьк і с. Світязь у майбутньому приведе до формування єдиного селитебно-рекреаційного центру, який спеціалізуватиметься на наданні рекреаційно-оздоровчих послуг на базі перспективного курорту «Світязь».

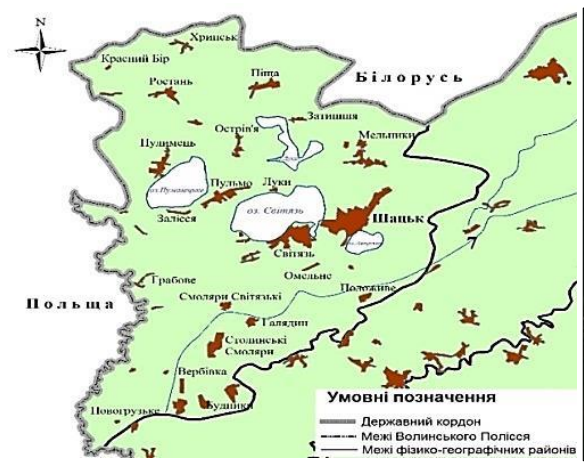

А. Населені пункти Шацького ФГР

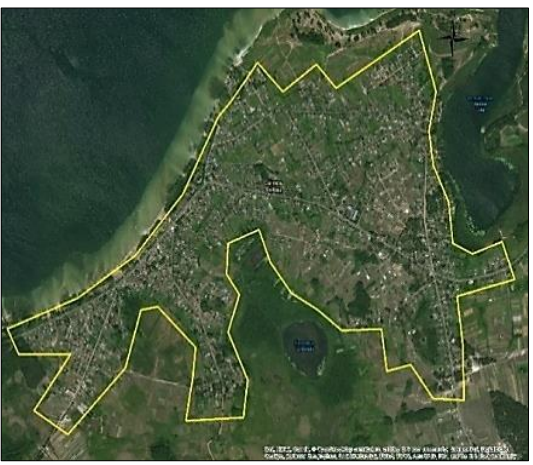

Б. Територіальні межі

с. Світязь на космознімку (робочий варіант для оцифрування площі)

\section{Рис. 3. Територіальна локалізація населених пунктів у межах модельного Шацького ФГР}


Аналогічно, як для Шацького модельного ФГР, була здійснена оцінка селитебного навантаження в межах усіх ФГР природної області Волинського Полісся (рис. 4). Найбільша частка селитебних земель $(8,59 \%)$ припадає на Маневицько-Володимирецький ФГР. Там розташовані два адміністративні районні центри, зокрема смт Маневичі та Володимирець, а також місто обласного підпорядкування Вараш. У складі ФГР налічується 79 населених пункти із загальною площею 170,3 км². Другу рангову позицію (6,1-7,0\% частка селитебних земель) посідає Колківсько-Сарненський $(6,11 \%)$ та Костопільсько-Березнівський $(6,05 \%)$ ФГР. Найменша частка площі $(2,44 \%)$ селитебних земель зосереджена у Льва-Горинському ФГР. Там і найменша кількість населених пунктів - 26, які займають площу лише 50,98 км². Це пояснюється тим, що в цьому районі значні площі займають болотні та водно-болотні природні комплекси, що 3 давнього часу було обмежуючим чинником щодо розвитку поселенської структури. Загальна площа населених пунктів природної області Волинського Полісся становить 1 413,72 км², середня частка селитебних земель - 5,19\%, кількість населених пунктів на 1 км $^{2}-4$ (табл. 2).

Таблиця 1

Кількість населення та площі населених пунктів модельного Шацького фізико-географічного району

\begin{tabular}{|c|c|c|c|c|}
\hline $\begin{array}{c}\text { № } \\
\mathbf{3} / \mathbf{I}\end{array}$ & Населений пункт & $\begin{array}{c}\text { Кількість } \\
\text { населення, станом } \\
\text { на 1 січня 2018 p. }\end{array}$ & $\begin{array}{c}\text { Площа, } \\
\text { км2 }^{\mathbf{2}}\end{array}$ & $\begin{array}{c}\text { Адміністративний } \\
\text { район }\end{array}$ \\
\hline 1 & Хрипськ & 277 & 0,825 & Шацький \\
\hline 2 & Красний Бір & 11 & 0,64 & Шацький \\
\hline 3 & Перешпа & 89 & 3,12 & Шацький \\
\hline 4 & Ростань & 410 & 1,158 & Шацький \\
\hline 5 & Піща & 1162 & 0,9 & Шацький \\
\hline 6 & Затишшя & 260 & 0,155 & Шацький \\
\hline 7 & Гаӥвка & 181 & 0,029 & Шацький \\
\hline 8 & Мельники & 1231 & 1,806 & Шацький \\
\hline 9 & Шацьк & 5340 & 5,75 & Шацький \\
\hline 10 & Положиве & 284 & 0,391 & Шацький \\
\hline 11 & Омельне & 244 & 0,458 & Шацький \\
\hline 12 & Голядин & 339 & 0,533 & Шацький \\
\hline 13 & Смоляри-Світязькі & 279 & 0,404 & Шацький \\
\hline 14 & Адамчуки & 74 & 0,147 & Шацький \\
\hline 15 & Грабове & 294 & 0,49 & Шацький \\
\hline 16 & Світязь & 1845 & 2,386 & Шацький \\
\hline 17 & Підманове & 472 & 0,47 & Шацький \\
\hline 18 & Вільшанка & 98 & 0,2 & Шацький \\
\hline 19 & Кошари & 60 & 0,25 & Шацький \\
\hline 20 & Залісся & 272 & 0,537 & Шацький \\
\hline
\end{tabular}


Продовження таблиці 1

\begin{tabular}{|c|c|c|c|c|}
\hline $\begin{array}{c}\text { № } \\
\text { 3/II }\end{array}$ & Населений пункт & $\begin{array}{c}\text { Кількість } \\
\text { населення, станом } \\
\text { на 1 січня 2018 p. }\end{array}$ & $\begin{array}{c}\text { Площа, } \\
\text { км² }^{\mathbf{2}}\end{array}$ & $\begin{array}{c}\text { Адміністративни } \\
\text { й район }\end{array}$ \\
\hline 21 & Пульмо & 1403 & 1,225 & Шацький \\
\hline 22 & Острів'я & 525 & 0,49 & Шацький \\
\hline 23 & Кам'янка & 134 & 0,001 & Шацький \\
\hline 24 & Пулимець & 667 & 0,875 & Шацький \\
\hline 25 & Пехи & 258 & 0,26 & Шацький \\
\hline 26 & Забужжя & 829 & 2,18 & Любомльський \\
\hline 27 & Локутки & 82 & 0,22 & Любомльський \\
\hline 28 & Вербівка & 88 & 0,24 & Любомльський \\
\hline 29 & Рогові Смоляри & 214 & 0,77 & Любомльський \\
\hline 30 & Будники & 197 & 0,53 & Любомльський \\
\hline 31 & Гороховище & 187 & 0,31 & Любомльський \\
\hline 32 & Новоугрузьке & 194 & 0,7 & Любомльський \\
\hline 33 & Столинські Смоляри & 661 & 1,41 & Любомльський \\
\hline 34 & Гуща & 995 & 1,16 & Любомльський \\
\hline & Усього & $\mathbf{1 9 6 5 6}$ & $\mathbf{3 1 , 0 2}$ & \\
\hline
\end{tabular}

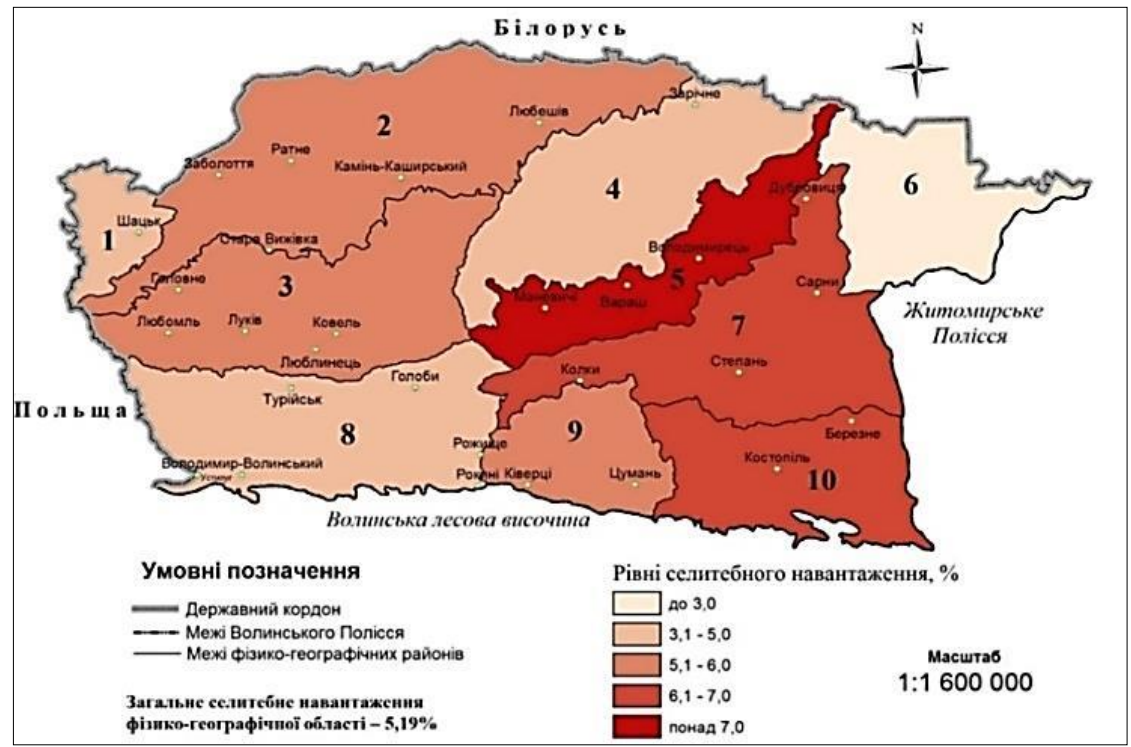

\section{Рис. 4. Селитебне навантаження на ландшафти Волинського Полісся}

Умовні позначення: 1-10- ФГР (підписи на рис. 2) 
Таблиця 2

\section{Оцінка селитебного та демографічного навантаження}

на ландшафти Волинського Полісся

\begin{tabular}{|c|c|c|c|c|c|c|c|c|}
\hline $\begin{array}{l}\text { № } \\
\text { 3/II }\end{array}$ & $\begin{array}{c}\text { Назва фізико- } \\
\text { географічного } \\
\text { району }\end{array}$ & 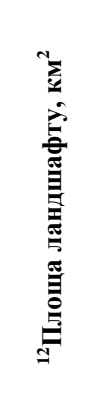 & 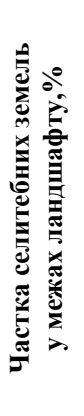 & 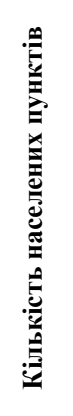 & 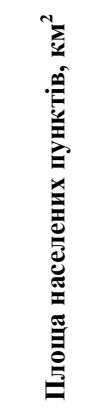 & 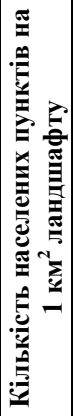 & 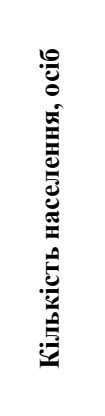 & 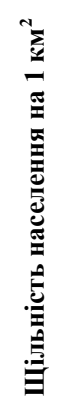 \\
\hline 1. & Шацький & 734,31 & 4,22 & 34 & 31,02 & 4,6 & 19656 & 26,8 \\
\hline 2. & Верхньоприп'ятський & 5014,73 & 5,45 & 209 & 273,34 & 4,2 & 188270 & 37,5 \\
\hline 3. & $\begin{array}{l}\text { Любомльсько- } \\
\text { Ковельський }\end{array}$ & 3561,44 & 5,19 & 134 & 184,98 & 3,8 & 154061 & 43,3 \\
\hline 4. & Нижньостирський & 3276,63 & 3,31 & 80 & 108,73 & 2,4 & 66179 & 20,2 \\
\hline 5. & $\begin{array}{c}\text { Маневицько- } \\
\text { Володимирецький }\end{array}$ & 1981,22 & 8,59 & 79 & 170,3 & 4,0 & 113792 & 57,4 \\
\hline 6. & Льва-Горинський & 2091,28 & 2,44 & 26 & 50,98 & 1,2 & 23637 & 11,3 \\
\hline 7. & $\begin{array}{l}\text { Колківсько- } \\
\text { Сарненський } \\
\end{array}$ & 3425,11 & 6,11 & 130 & 209,2 & 4,0 & 164164 & 48,0 \\
\hline 8. & $\begin{array}{c}\text { Турійсько- } \\
\text { Рожищенський }\end{array}$ & 3375,78 & 4,85 & 206 & 163,65 & 6,1 & 115672 & 34,3 \\
\hline 9. & $\begin{array}{l}\text { Ківерцівсько- } \\
\text { Цуманський }\end{array}$ & 1454,02 & 5,55 & 67 & 80,72 & 4,6 & 55324 & 38,0 \\
\hline 10. & $\begin{array}{l}\text { Костопільсько- } \\
\text { Березнівський }\end{array}$ & 2324,98 & 6,05 & 107 & 140,8 & 4,6 & 117821 & 50,7 \\
\hline & Разом & 27239,5 & 5,19 & 1072 & 1413,72 & 4,0 & $\begin{array}{l}998 \\
920\end{array}$ & 36,7 \\
\hline
\end{tabular}

Наступним етапом наших досліджень була оцінка демографічного навантаження на ландшафти Волинського Полісся. За результатами демографічної статистики (табл. 2) нами побудована картографічна модель ранжування ФГР за кількістю населення (рис. 5). Найвищий ранг (188,3 тис. осіб) із п'яти градацій у Верхньоприп'ятського ФГР. У цьому ФГР розташовані чотири районні центри, зокрема: КаміньКаширський (12,5 тис. осіб), Любешів (5,8 тис. осіб), Ратне (9,9 тис. осіб), Стара Вижівка (5,2 тис. осіб). На другому місці - КолківськоСарненський (164,2 тис. осіб) та Любомльсько-Ковельський (154,1 тис.

12 Мартинюк В. Регіональне ландшафтно-гідрографічне ГІС-моделювання поверхневих вод Полісся. Прыроднае асяроддзе Палесся : асаблівасиі $i$ nерспектывы развіция : зборнік навуковых прац. Брэст : Альтернатива, 2018. Вып. 11. С. 70-73. 
осіб) ФГР. Остання рангова позицію за кількістю населення - ЛьваГоринський (23,6 тис. осіб) та Шацький (19,7 тис. осіб) ФГР.

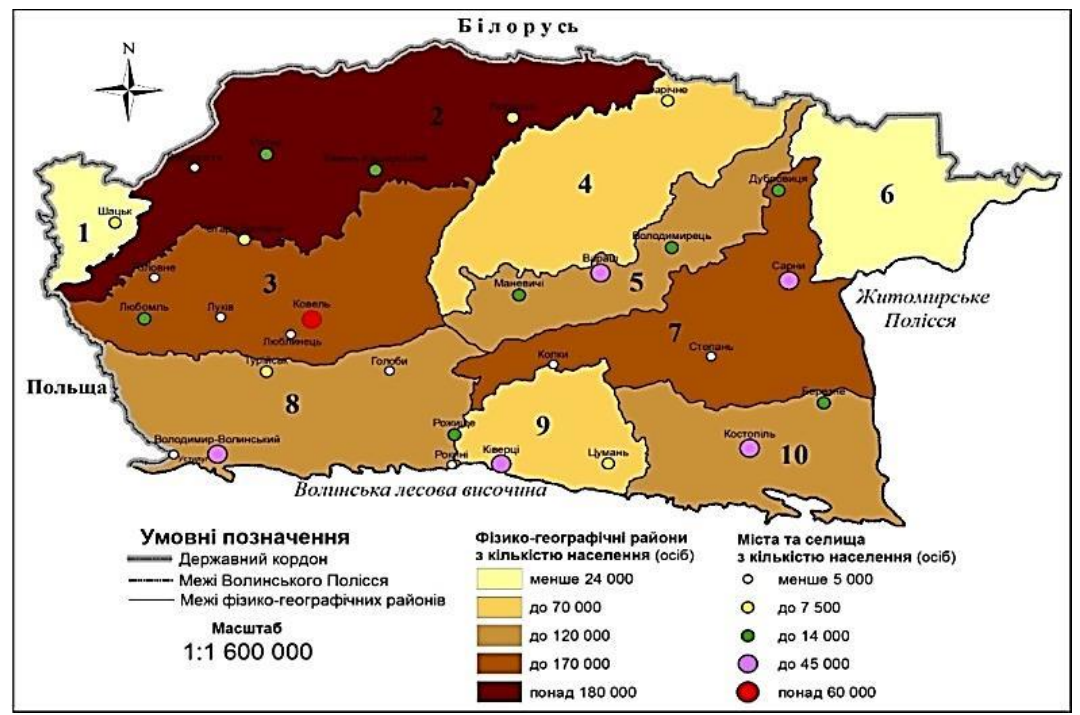

\section{Рис. 5. Ранжування фізико-географічних районів Волинського Полісся за кількістю населення}

Умовні позначення: 1-10 - ФГР (підписи на рис. 2)

Важливим показником антропогенного навантаження на ландшафти $\epsilon$ густота (або щільність) населення на $1 \mathrm{kм}^{2}$. Розрахунки цього показника дозволили виявити, що найвища густота населення в Маневицько-Володимирецькому (57,4 осіб на 1 км²) та КостопільськоБерезнівському (50,7 осіб на 1 км$\left.^{2}\right)$ районах. У цих районах, як згадувалося вище, один із найвищих показників селитебного навантаження на ландшафти. На другому місці за щільністю населення - Колківсько-Сарненський (48 осіб на 1 км $\left.^{2}\right)$ та Любомльсько-Ковельський $\left(43,3\right.$ осіб на 1 км$\left.^{2}\right)$ ФГР. Найменш густозаселеним природним районом Волинського Полісся $є$ ЛьваГоринський ФГР. Показник щільності населення тут становить лише

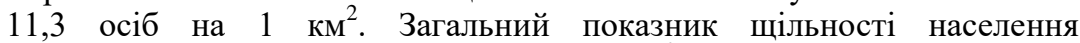
Волинського Полісся - 36,7 осіб на 1 км²$^{2}$. Для порівняння, густота населення України (станом на 1 січня 2019 р.) становила 70,5 осіб на $1 \mathrm{kм}^{2}$. Більш детально демографічне навантаження на ландшафти Волинського Полісся за густотою населення показано на рис. 6. 


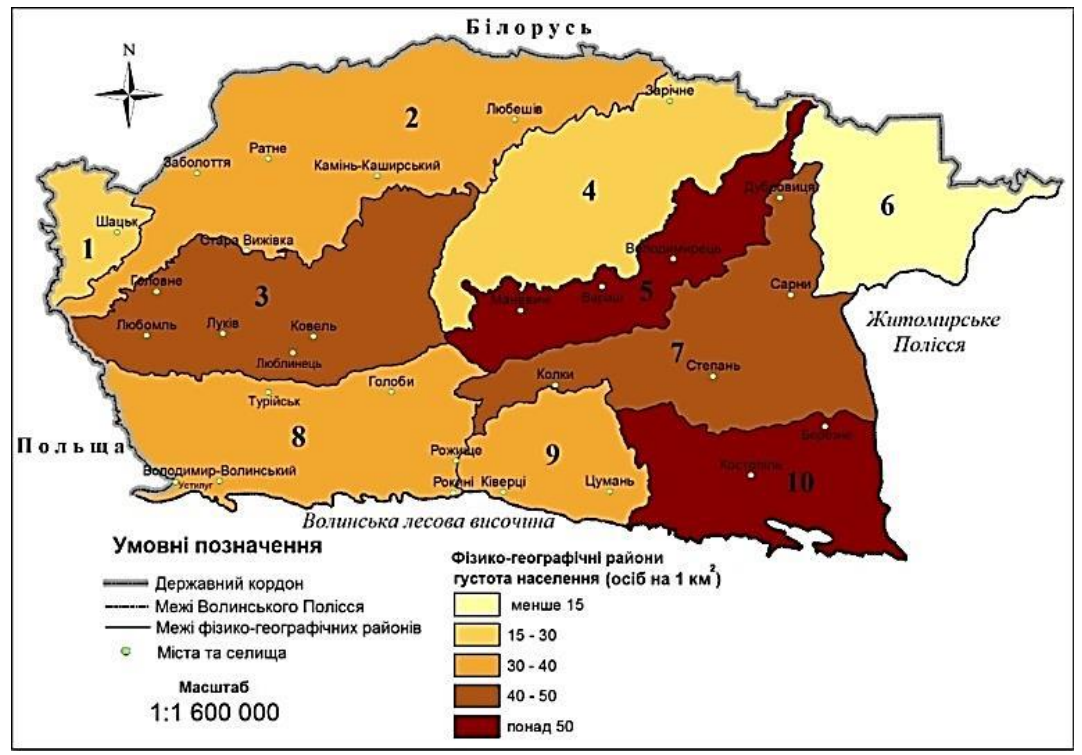

Рис. 6. Демографічне навантаження на ландшафти Волинського Полісся за густотою населення.

Умовні позначення: 1-10-ФГР (підписи на рис. 2)

\section{2. Оцінка геоекологічного стану озерно-басейнових систем}

Встановлення особливостей селитебного та демографічного навантаження на ландшафти Волинського Полісся послужило основою для оцінки геоекологічного стану локальних територій, зокрема ОБС. Виділення ОБС грунтувалося на топографічних картах масштабу 1:10 000, космознімках високої роздільної здатності 3 підвантаженням цифрових моделей рельєфу даних SRTM та застосуванням програмного пакету ArcGIS 10.3. Оцінка геоекологічного стану ОБС включала картографування просторово-типологічної структури угідь басейнів, виявлення співвідношення площ антропогенно-трансформованих угідь (далі - АТУ) до еколого-стабілізуючих угідь (далі - ЕСУ) у межах ОБС. Модифікована шкала для оцінки геоекологічного стану ОБС наведена в табл. 3, а формула коефіцієнта господарського освоєння водозбору $\left(K_{\boldsymbol{\Gamma}}\right)$ виглядає так: $\boldsymbol{K}_{\boldsymbol{\Gamma} \boldsymbol{O}}=\frac{\boldsymbol{s} \text { АТУ }}{\boldsymbol{S} \text { ЕСУ }}$.

Для оцінки геоекологічного стану ОБС було обрано 11 модельних водозборів Волинського Полісся (рис. 7), які розташовані в різних ФГР, 3 не однаковим ступенем господарського освоєння. 


\section{Таблиця 3}

Модифікована шкала для оцінки

геоекологічного стану басейнів озер ${ }^{13}$

\begin{tabular}{|c|c|c|c|c|}
\hline \multirow{2}{*}{$\begin{array}{c}\text { ТиІ } \\
\text { водозбору (за } \\
\text { рангом) }\end{array}$} & \multirow{2}{*}{$\begin{array}{c}\text { Тип водозбору } \\
\text { (за Ф. Мільковим) }\end{array}$} & \multicolumn{2}{|c|}{$\begin{array}{c}\text { Питома вага угідь, \% до } \\
\text { їхньої сумарної площі }\end{array}$} & \multirow{2}{*}{$\begin{array}{c}\text { Геоекологічний } \\
\text { стан }\end{array}$} \\
\hline & & ATY & ECY & \\
\hline 0 & \multirow{2}{*}{ природний } & $<5,0$ & $>95,0$ & еталонний \\
\hline I & & $5,1-20,0$ & $94,9-80,0$ & оптимальний \\
\hline II & \multirow{2}{*}{$\begin{array}{c}\text { природно- } \\
\text { антропогенний }\end{array}$} & $20,1-40,0$ & $79,9-60,0$ & добрий \\
\hline III & & $40,1-55,0$ & $59,9-45,0$ & задовільний \\
\hline IV & $\begin{array}{c}\text { антропогенно- } \\
\text { природний }\end{array}$ & $55,1-80,0$ & $44,9-20,0$ & незадовільний \\
\hline V & антропогенний & $>81,0$ & $<19,9$ & критичний \\
\hline
\end{tabular}

Коеріцієнт господарського освоєння водозбору $\left(\boldsymbol{K}_{\text {го): }}<0,1-\right.$ дуже низький;

0,1-0,25 - низький; 0,26-0,50-середній; 0,51-0,75- підвищений; 0,76-1,0-високий; 1,1-1,5 - дуже високий; >1,6 - надзвичайно високий.

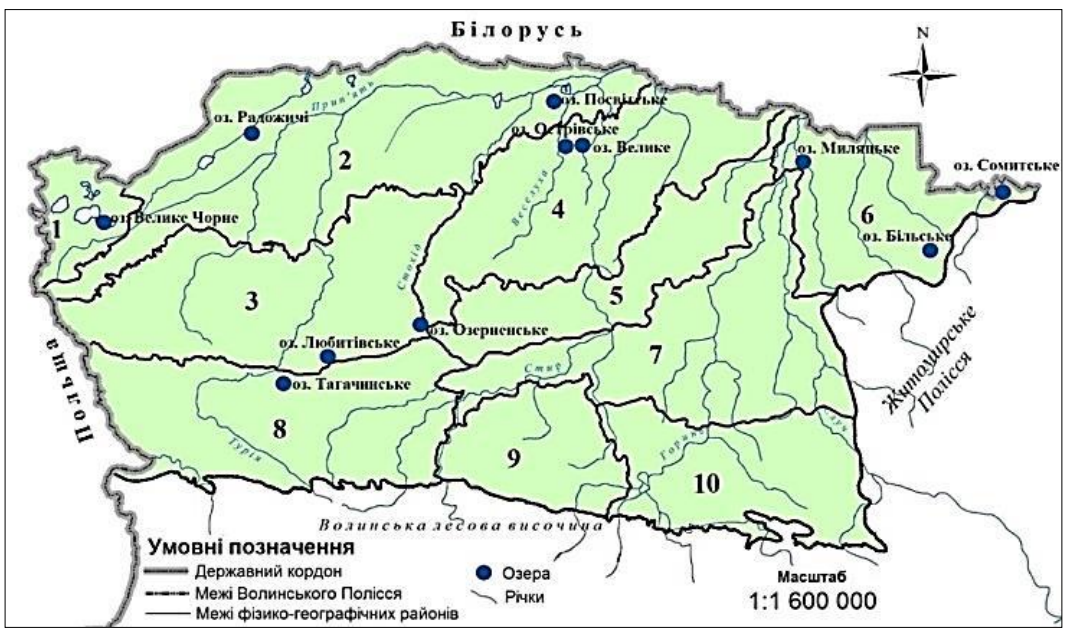

\section{Рис. 7. Модельні ОБС Волинського Полісся для оцінки геоекологічного стану.}

Умовні позначення: 1-10-ФГР (підписи на рис. 2)

Розглянемо особливості просторово-типологічної структури та геоекологічного стану ОБС модельних водозборів. У межах Шацького

13 Зубкович I., Мартинюк В., Андрійчук С. Оцінка геоекологічного стану басейнової системи озера Радожичі із застосуванням геоінформаційних технологій. Науковий вісник Східноєвропейськогого начіонального університету імені Лесі Українки. Серія «Географічні науки». 2019. № 9 (393). С. 27-36. 
ФГР нами виділено басейн о. Чорне Велике (рис. 8), який розташований у південній частині смт Шацьк (кількість населення 5340 осіб). Площа ОБС, за нашими оцінками, становить 366,32 га.

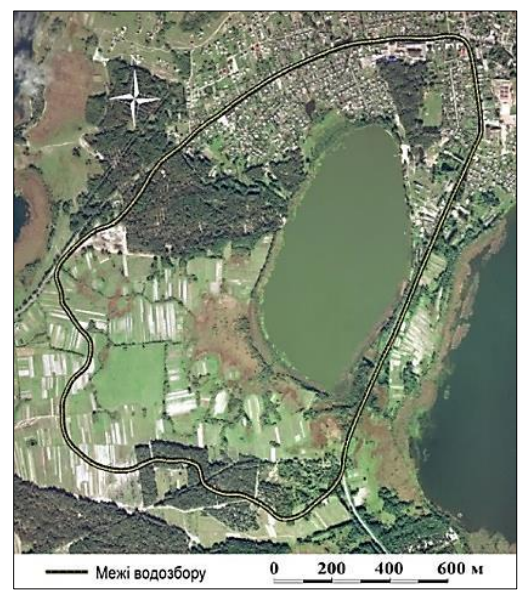

a) межі ОБС на космознімку (Landsat 7)

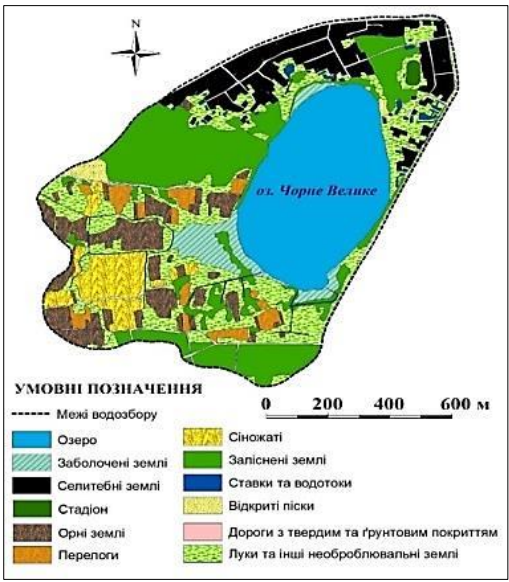

б) картографічна модель земельних угідь ОБС

\section{Рис. 8. Модель просторово-типологічної структури угідь басейну о. Чорне Велике}

Найбільшу площу $(22,3 \%)$ у структурі угідь займає саме озеро, на другому місці - заліснені землі, луки та необроблювані землі - по $21,2 \%$, селитебні землі становлять $10,5 \%$, орні землі - 8,45\%, сіножаті $5,25 \%$, заболочені землі - 3,8\%, перелоги і дороги із твердим і грунтовим покриттям - 3\% (рис. 9). Розрахований $\boldsymbol{K}_{\boldsymbol{\Gamma}}$ в водозбору о. Чорне Велике виглядає так:

$$
\boldsymbol{K}_{\boldsymbol{\Gamma} \boldsymbol{O}}=\frac{\boldsymbol{S} \text { АТУ }}{\boldsymbol{S} \text { ЕСУ }}=\frac{116,37 \text { га }}{249,95 \text { га }}=0,47,
$$

де $\boldsymbol{S}_{\boldsymbol{A T y}}$ - селитебні землі, дороги, орні землі, сіножаті, сади, ставки та водотоки; $\boldsymbol{S}_{\boldsymbol{E} \boldsymbol{C y}}$ - заболочені землі, водні об'єкти, деревна та чагарникова рослинність, інші необроблювальні землі. За критерієм співвідношення АТУ/ЕСУ водозбір озера характеризується добрим геоекологічним станом (II ранговий тип водозбору, оскільки АТУ становить $24,98 \%$, а ЕСУ - 75,02\%), а ступінь господарського освоєння водозбору середній. 


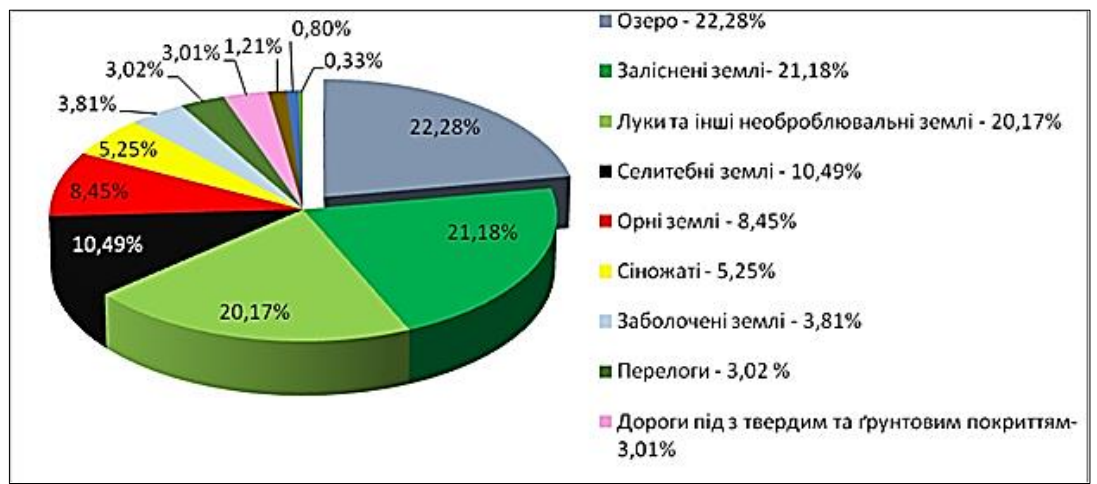

\section{Рис. 9. Типологічна структура земельних угідь водозбору о. Чорне Велике}

У межах Льва-Горинського ФГР модельним басейном обрано о. Миляцьке, розташоване в місцевості понижених плоских межиріч, ускладнених невеликими горбами та карстовими лійками на воднольодовикових відкладах із близьким заляганням крейди. Особливістю географічного розташування ОБС є те, що в іiі межах (за 80-90 м на північ від берега водойми) побудована сільськогосподарська тваринницька ферма, зі східної та південної частини водозбору прилягають селитебні землі с. Миляч (1 118 осіб), а із заходу перехоплює поверхневий стік і обмежує площу сточища меліоративна система. Площа басейнової системи становить 87,35 га.

Картографічна модель структури земельних угідь ОБС о. Миляч (рис. 10$)$ показала, що найбільшу частку $(23,2 \%)$ займають селитебні землі, на шляхові комунікації припадає майже $8 \%$, площа с/г ферми становить $5,4 \%$; загалом на АТУ водозбору припадає $58,15 \%$. У структурі ЕСУ приблизно 18\% займає площа самого озера, 16,2\% луки та необроблювані землі, 6,4\% - заліснені землі, 5\% становлять відкриті піски; частка земель ЕСУ - 41,85\%. Більш детально структура земельних угідь водозбору о. Миляцьке наведена на рис. 11. За результатами співвідношення площ АТУ до ЕСУ ми визначили коефіцієнт господарського освоєння водозбору, зокрема:

$$
\boldsymbol{K}_{\boldsymbol{\Gamma} \boldsymbol{O}}=\frac{\boldsymbol{s} \text { ATУ }}{\boldsymbol{S} \text { ЕСУ }}=\frac{50,7982}{36,5562}=1,39 .
$$




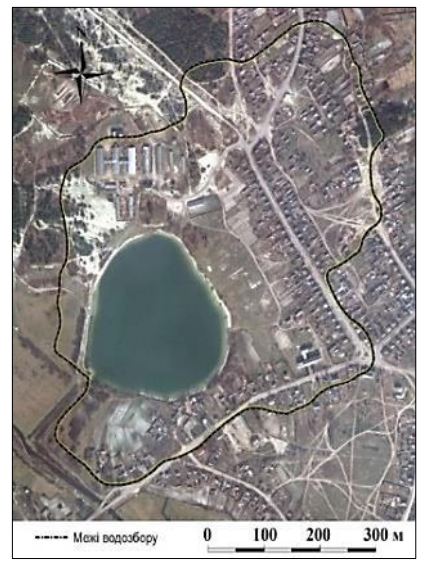

a) межі ОБС на космознімку (Landsat7)

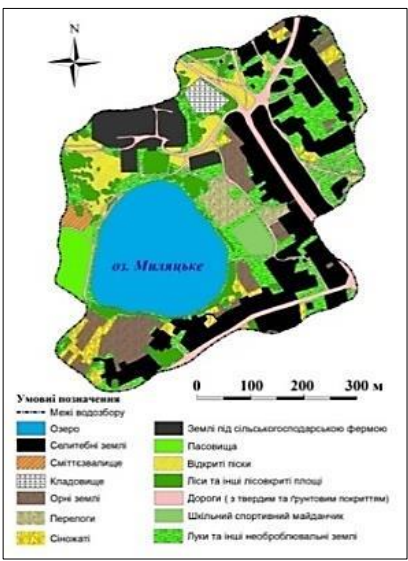

б) картографічна модель земельних угідь ОБС

Рис. 10. Модель просторово-типологічної структури угідь басейну о. Миляцьке ${ }^{14}$

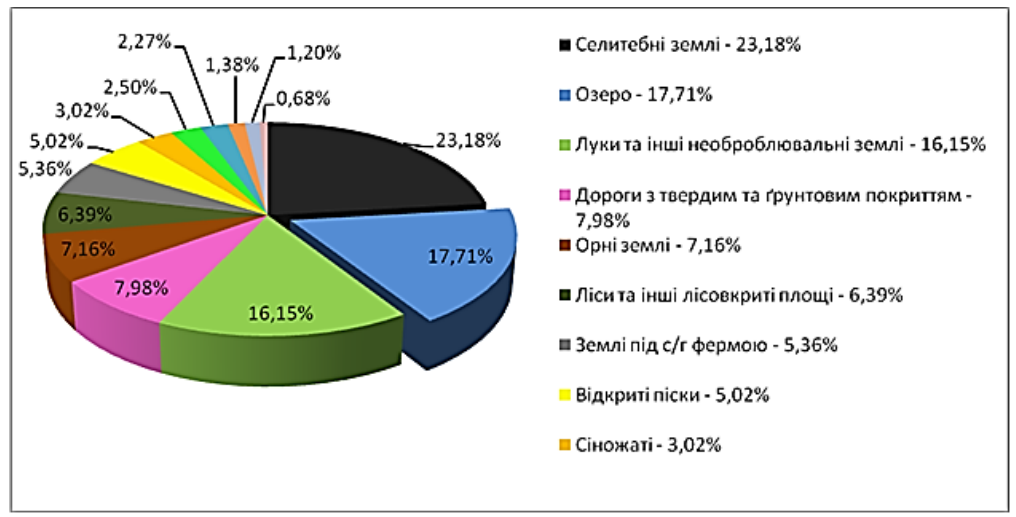

\section{Рис. 11. Типологічна структура земельних угідь водозбору о. Миляцьке}

За критерієм співвідношення АТУ/ЕСУ басейнова система о. Миляцьке характеризується незадовільним геоекологічним станом, вона відноситься

14 Зубкович I. Геоекологічна оцінка стану водозбору озера Миляцьке (Волинське Полісся) за даними ДЗЗ. Наука, освіта, сvспільство очима молодих : матеріали XII Міжнародної науково-практичної конференції здобувачів вищої освіти і молодих науковців. Рівне : РВВ РДГУ, 2019. С. 87-189. 
до антропогенно-природного типу водозбору (IV ранг). Ступінь господарського освоєння водозбору $(1,39) \epsilon$ дуже високим.

У Любомльсько-Ковельському ФГР модельним басейном було обрано о. Любитівське, яке сформувалося в ландшафтній місцевості зандрових рівнин із зеленомоховими і чорничниковими сосняками 3 домішкою дрібнолистяних порід на водно-льодовикових відкладах із близьким заляганням крейдо-мергелів. Площа водозбору озера, за нашими оцінками ${ }^{15}$, становить 71,5471 га. ОБС розташована в центрі с. Любитів (1 436 осіб). За результатами польових досліджень із застосуванням ГІС-технологій нами побудована картографічна модель просторово-типологічної структури угідь ОБС о. Любитівське (рис. 12).

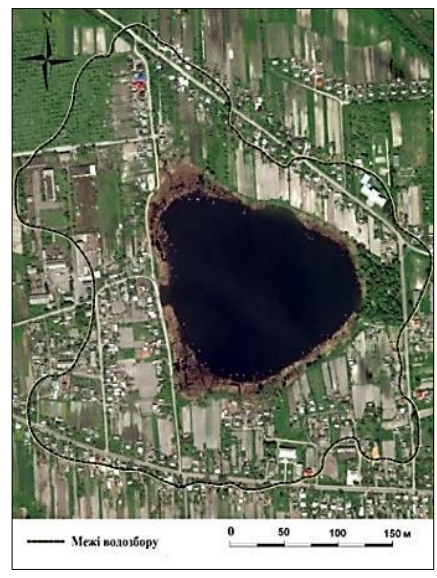

a) межі ОБС на космознімку (Landsat 7)

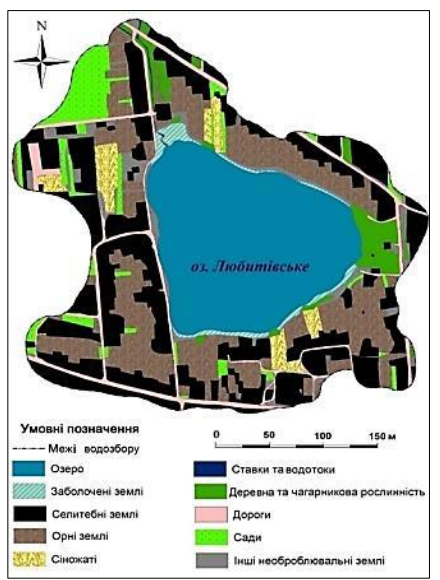

б) картографічна модель земельних угідь ОБС

\section{Рис. 12. Модель просторово-типологічної структури угідь басейну о. Любитівське}

За критерієм співвідношення АТУ/ЕСУ водозбір о. Любитівське характеризується незадовільним геоекологічним станом (відноситься до IV рангового типу за господарським освоєнням, оскільки АТУ становить 63,23\%, а ЕСУ - 36,77\%). Розрахунки коефіцієнта господарського освоєння водозбору наведені нижче:

15 Мартинюк В., Зубкович I., Андрійчук С. Ландшафтно-географічна оцінка ресурсного потенціалу сапропелю озера Любитівське (Волинське Полісся). Людина та довкілля. Проблеми неоекологї. 2018. Вип. 30. С. 91-103. DOI: 10.26565/19924224-2018-30-07. 


$$
\boldsymbol{K}_{\boldsymbol{\Gamma} \boldsymbol{O}}=\frac{\boldsymbol{S} \text { АТУ }}{\boldsymbol{S} \text { ЕСУ }}=\frac{45,234926}{26,312182}=1,72 .
$$

Вони показали надзвичайно високий ступінь антропогенізації загалом в ОБС. Загальнаструктура земельних угідь водозбору виглядає так: озеро - 27,9\%, селитебні землі - 27,75\%, орні угіддя $-21,08 \%$, дороги із твердим і грунтовим покриттям - 5,6\%, сіножаті $-3,21 \%$. Більш детально типологічна структура земельних угідь водозбору о. Любитівське наведена на рис. 13.

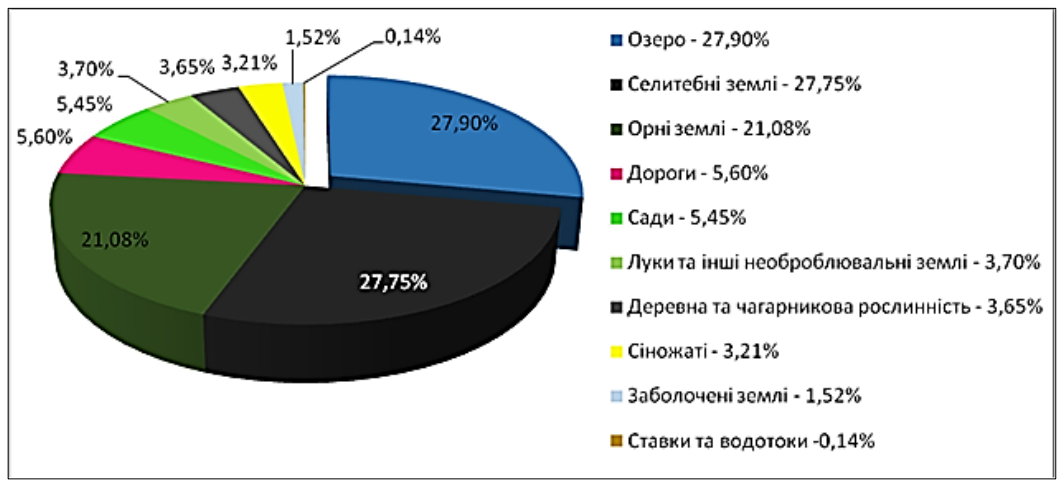

Рис. 13. Типологічна структура земельних угідь водозбору о. Любитівське

У Турійсько-Рожищенському ФГР ключовим об'єктом 3 оцінки геоекологічного стану ОБС обрано о. Тагачинське. ОБС сформувалася в місцевості слабодренованих межиріч із переважанням чорновільхових i дубово-соснових лісів на водно-льодовикових відкладах із близьким заляганням крейди. За нашими оцінками, площа водозбору озера становить 108,5185 га (рис. 14). На південь від водойми розташоване с. Тагачин (295 осіб) 3 орними землями присадибних господарств та сільськогосподарською фермою. Приозерна тераса частково заболочена, локально заліснена і вкрита луками.

Оцінка типологічної структури угідь ОБС показала, що орні землі займають $41,3 \%$, землі під с/г фермою - 5,3\%, сіножаті - 4,8\%, шляхові комунікації - 4,1\%, землі під житловою забудовою - 3,9\%, ставки $0,5 \%$ (рис. 15). Частка АТУ в межах басейнової системи становить $59,9 \%$, а на частку ЕСУ припадає $41,1 \%$. 


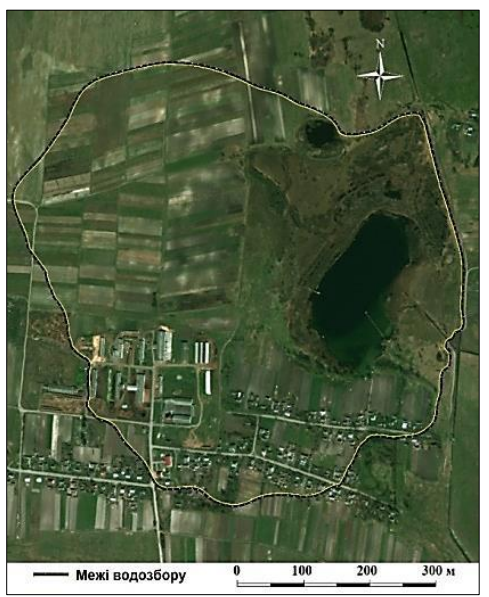

a) межі ОБС на космознімку (Landsat 7)

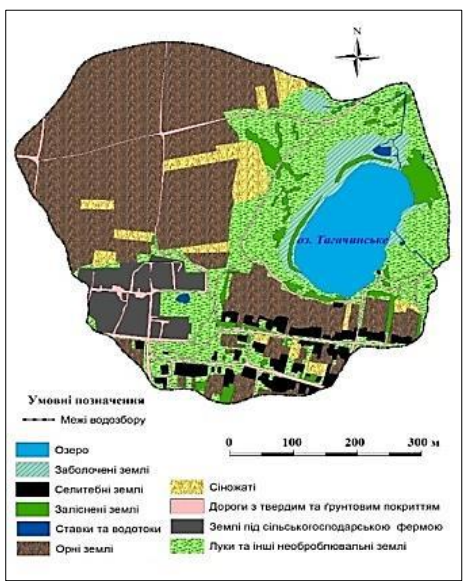

б) картографічна модель земельних угідь ОБС

\section{Рис. 14. Модель просторово-типологічної структури угідь басейну о. Тагачинське}

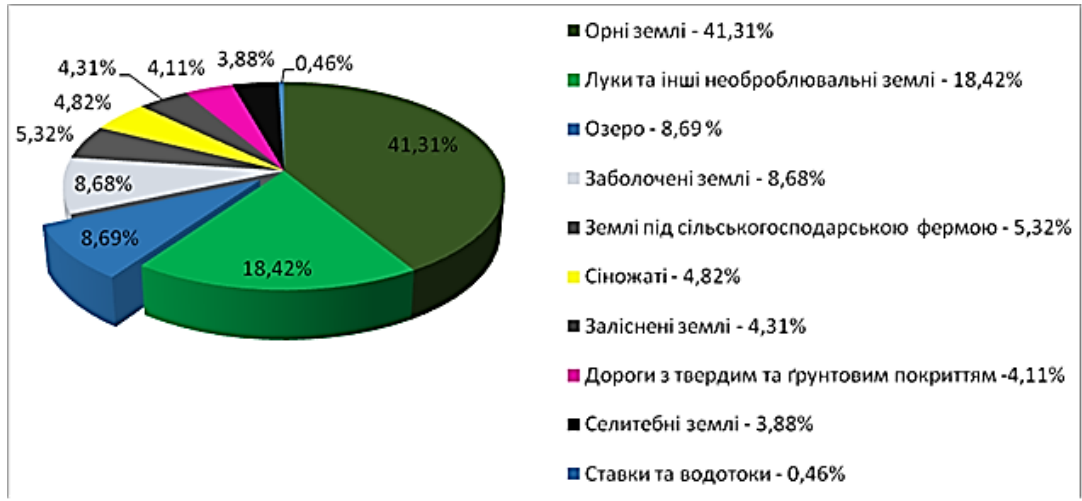

\section{Рис. 15. Типологічна структура земельних угідь водозбору о. Тагачинське}

Коефіцієнт господарського освоєння водозбору виглядає так:

$$
\boldsymbol{K}_{\boldsymbol{\Gamma} \boldsymbol{O}}=\frac{\boldsymbol{S} \text { ATУ }}{\boldsymbol{S} \text { ЕСУ }}=\frac{64,9938}{43.5247}=1,49 .
$$


За критерієм співвідношення АТУ/ЕСУ водозбір о. Тагачинське характеризується незадовільним геоекологічним станом, відноситься до IV рангу за типом господарського освоєння. Ступінь господарського освоєння водозбору, за нашою оцінкою, дуже високий.

Стосовно геоекологічного стану інших ОБС Волинського Полісся, які детально не аналізувалися, наводимо схему співвідношення АТУ/ЕСТУ (рис. 16).

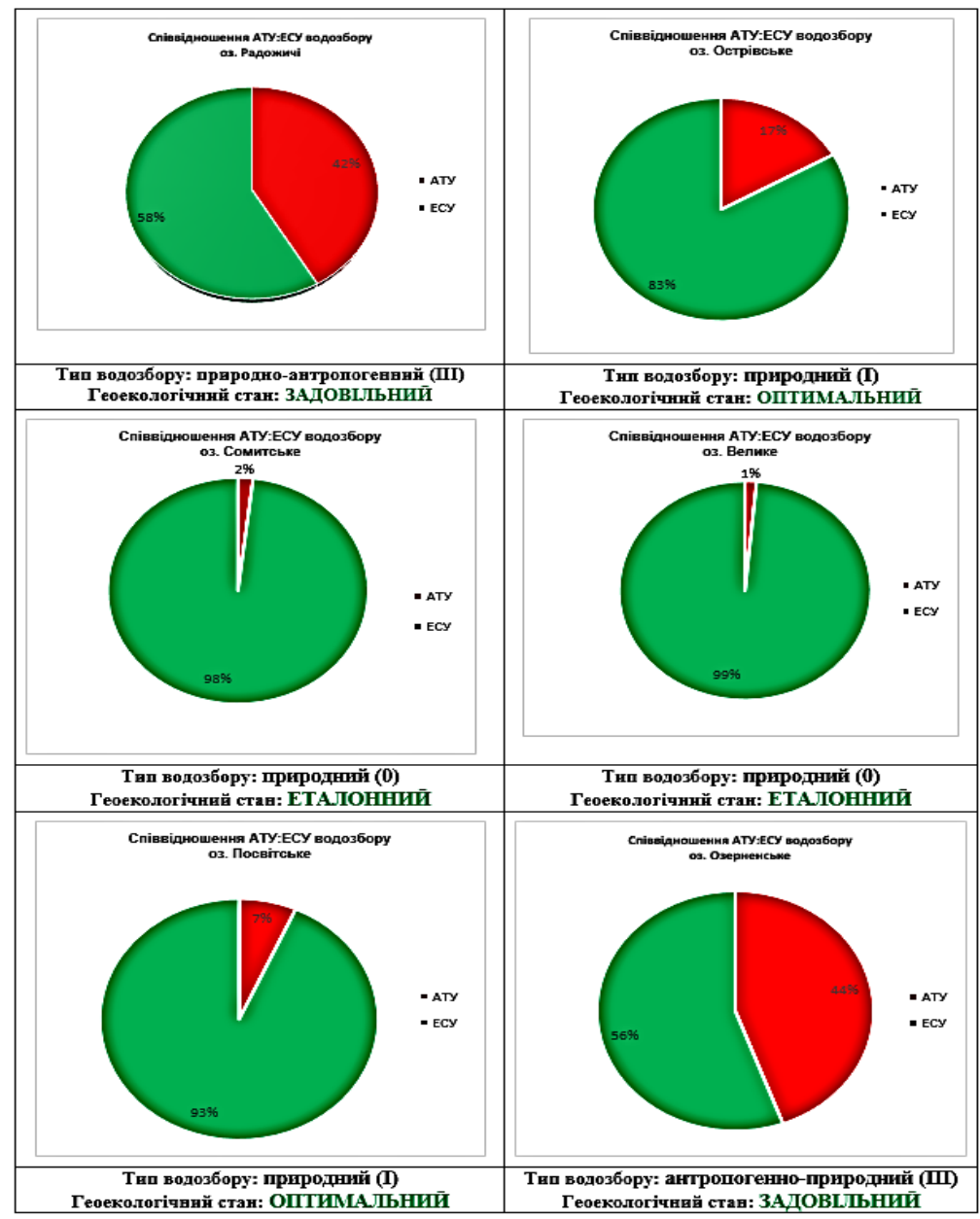

Рис. 16. Геоекологічний стан басейнів озер за співвідношенням АТУ/ЕСУ 


\section{ВИСНОВКИ}

За результатами проведених досліджень нами встановлено, що

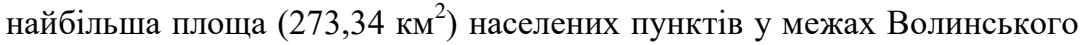
Полісся історично сформувалася у Верхньоприп'ятському ФГР. Найбільша частка селитебних земель $(8,59 \%)$ у МаневицькоВолодимирецькому ФГР. отже, він зазнає найбільшого антропогенного навантаження. Найменша частка селитебного навантаження (2,44\%) спостерігається у Льва-Горинському ФГР. У цьому природному районі зафіксована найменша кількість (26 шт.) та площа $\left(50,98\right.$ км$\left.^{2}\right)$ населених пунктів. Важливим геоекологічним показником, що визначає антропогенне навантаження на ландшафти, $€$ кількість населених пунктів на 1 км$^{2}$ території. Найвищий цей показник $\left(6,1\right.$ шт. на 1 км$\left.^{2}\right)$ у Турійсько-Рожищенському ФГР, а найменший (1,2 шт. на 1 км$\left.^{2}\right)-$ у Льва-Горинському ФГР. Оціночні характеристики демографічного навантаження на ландшафти Волинського Полісся показали, що найбільша кількість населення (188 270 осіб $)$ проживає у Верхньоприп'ятському ФГР, а найменша (19 656 осіб) - у Шацькому ФГР. За щільністю населення цей показник $є$ найвищим $\left(57,4\right.$ на 1 км$\left.^{2}\right)$

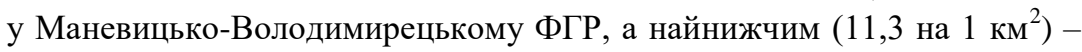
у Льва-Горинському ФГР. За оцінкою демографічного і селитебного навантаження на ландшафти Волинського Полісся, найменшого антропогенного тиску зазнає Льва-Горинський ФГР. Обмежуючим чинником $\epsilon$ високе радіоактивне забруднення ландшафтів цього природного району внаслідок катастрофи на Чорнобильській $\mathrm{AEC}^{16}$.

Геоекологічна діагностика ключових ОБС Волинського Полісся, 3 урахуванням селитебного та демографічного навантаження на ландшафти, показала незадовільний геоекологічний стан на трьох водозборах (озера Любитівське, Миляцьке, Тагачинське), де частка АТУ становить від 58,15 до 63,23\%. Задовільний геоекологічний стан встановлено на двох водозборах (озера Озерненське, Радожичі); тут частка АТУ становить від 41,62 до 44,4\%. Добрий геоекологічний стан виявлено на двох водозборах (озера Більське, Чорне Велике) із часткою АТУ від 21,02 до 24,98\%. 3 оптимальним геоекологічним станом

16 Мартинюк В. Радіоактивне забруднення фізико-географічних районів Волинського Полісся. Natural Resources of Border Areas under a Changing Climate : The $3^{\text {rd }}$ International Scientific Conference: the program, abstracts, Ukraine, Chernihiv, September 24-27, 2019. Chernihiv : Desna Polygraph Publishing House, 2019. P. 49. 
басейни озер Острівське і Посвітське (АТУ від 16,81 до 21,02\%), 3 еталонним станом водозбори озер Велике і Сомитське (АТУ від 1,46 до $1,86 \%)$.

Першочергових заходів із проведення оптимізації природокористування потребують басейнові системи озер Миляцьке, Тагачинське та Любитівське. У цих ОБС $\boldsymbol{\kappa}_{\boldsymbol{I} о}$ водозборів дуже високий $(1,39-1,49)$ та надзвичайно високий $(1,72)$. Такі завдання мають бути покладені на новостворені ОТГ, районні екологічні інспекції та басейнові управління водних ресурсів. Результати геоекологічної діагностики ОБС мають стати основою для ландшафтного планування та збалансованого природокористування ОТГ із визначенням конкретної господарської спеціалізації цих локальних територій.

\section{АНОТАЦІЯ}

У зв'язку зі зростанням антропогенного навантаження (селитебного, демографічного, меліоративного, аграрно-промислового тощо) на природні комплекси Волинського Полісся, а також глобальними змінами клімату актуалізуються питання оцінки геоекологічного стану фізико-географічних районів та локальних парагенетичних систем, зокрема озерно-басейнових систем (ОБС), які сформувалися в межах конкретних ландшафтів. Такі дослідження пов'язані 3 розробкою стратегії збалансованого природокористування нових адміністративних територій - об'єднаних територіальних громад (ОТГ), де озернобасейнові системи мають посісти важливе місце як природногосподарські системи (ПГС).

Обгрунтовується частка селитебних земель у межах фізикогеографічних районів Волинського Полісся, проаналізовано загальну кількість та площі населених пунктів у межах регіону та їх розподіл за фізико-географічними районами, розраховано кількість населених

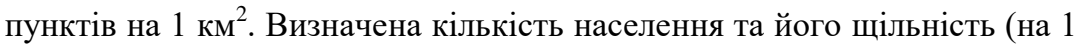
км$^{2}$ ) у межах фізико-географічних районів Волинського Полісся. Побудовано картографічні моделі селитебного та демографічного навантаження на ландшафти Волинського Полісся, здійснено ранжування фізико-географічних районів за кількістю населення.

На основі польових досліджень та із застосуванням ГІС-технологій здійснено геоекологічну діагностику одинадцяти озерно-басейнових 
систем Волинського Полісся. Побудовано картографічні моделі просторово-типологічної структури земельних угідь чотирьох озернобасейнових систем, визначено частку кожного зі структурних елементів ландшафту водозбору. Здійснена оцінка геоекологічного стану озернобасейнових систем за співвідношенням антропогеннотрансформованих угідь до еколого-стабілізуючих. Розраховано коефіцієнти господарського освоєння модельних озерно-басейнових систем. Запропоновано основні заходи 3 оптимізації збалансованого природокористування озерно-басейнових систем.

\section{ЛІТЕРАТУРА}

1. Зубкович I. Геоекологічна оцінка стану водозбору озера Миляцьке (Волинське Полісся) за даними ДЗЗ. Наука, освіта, суспільство очима молодих : матеріали ХІІ Міжнародної науковопрактичної конференції здобувачів вищої освіти і молодих науковців. Рівне : РВВ РДГУ, 2019. С. 87-189.

2. Зубкович І., Мартинюк В., Андрійчук С. Оцінка геоекологічного стану басейнової системи озера Радожичі із застосуванням геоінформаційних технологій. Науковий вісник Східноєвропейського національного університету імені Лесі Украйнки. Серія «Географічні науки». 2019. № 9 (393). С. 27-36.

3. Ільїн Л. Лімнокомплекси Українського Полісся : монографія : у 2-х т. Т. 2 : Регіональні особливості та оптимізація. Луцьк : РВВ «Вежа» Волин. нац. ун-ту імені Лесі Українки, 2008. 400 с.

4. Ільїна О., Кукурудза С. Болотні геокомплекси Волині : монографія. Львів : Вид-й центр ЛНУ імені Івана Франка, 2009. 242 с.

5. Идрисова Р. Комплексная оценка современного состояния ландшафтов Чеченской Республики. Вопросы современной науки и практики. Университет им. В.И. Вернадского. 2008. Т. 2. № 4 (14). C. $47-51$.

6. Койнова I. Антропогенна трансформація ландшафтних систем західної частини Волинського Полісся : автореф. дис. ... канд. геогр. наук: 11.00.11. Львів, 1999. 19 с.

7. Ландшафтно-екологічні дослідження у 30-кілометровій зоні Рівненської АЕС : основні результати, досвід використання ГІС / Л. Малишева та ін. Український географічний журнал 2003. № 1. С. 21-32. 
8. Мартинюк В. Ландшафтометрична оцінка геокомплексів фізикогеографічного району (на прикладі Волинського Полісся). Наукові записки Тернопільського державного педагогічного університету. Серія «Географія». 2016. № 2 (41). С. 65-72.

9. Мартинюк В. Оцінка ландшафтної структури локальних територій Волинського Полісся для потреб збалансованого природокористування. Науковий вісник Херсонського державного університету. Серія «Географічні науки». 2017. Вип. 6. С. 152-159.

10. Мартынюк В. Модель геоэкологического состояния озернобассейновой системы. Веснік Брэсикага ўніверсітэта. Серыя 5 «Хімія. Біялогія. Навукі аб зямлі». 2018. № 2. С. 108-116.

11. Мартинюк В. Регіональне ландшафтно-гідрографічне ГІС-моделювання поверхневих вод Полісся. Прыроднае асяроддзе Палесся : асаблівасиі і перспектывы развіция : зборнік навуковых прац. Брэст : Альтернатива, 2018. Вып. 11. С. 70-73.

12. Мартинюк В., Зубкович I. Ландшафтно-географічна модель екологічного паспорта басейнової системи озера Озерце (Волинське Полісся). Людина та довкілля. Проблеми неоекології. 2017. № № 3-4. C. 29-39.

13. Мартинюк В., Зубкович I., Андрійчук С. Ландшафтно-географічна оцінка ресурсного потенціалу сапропелю озера Любитівське (Волинське Полісся). Людина та довкілля. Проблеми неоекології. 2018. Вип. 30. C. 91-103. DOI: 10.26565/1992-4224-2018-30-07.

14. Мартинюк В. Радіоактивне забруднення фізико-географічних районів Волинського Полісся. Natural Resources of Border Areas under a Changing Climate : The $3^{\text {rd }}$ International Scientific Conference: the program, abstracts, Ukraine, Chernihiv, September 24-27, 2019. Chernihiv : Desna Polygraph Publishing House, 2019. P. 49.

15. Міщенко О. Ландшафти Волинської області. Наукові записки Тернопільського начіонального педагогічного університету імені Володимира Гнатюка. Серія «Географія». 2016. № 2. С. 72-77.

16. Ничая О. Сільські селитебні ландшафти Волинської області: сучасний стан та шляхи збалансованого розвитку : автореф. дис. ... канд. геогр. наук: 11.00.11. Луцьк, 2019. 20 с.

17. Сорокіна Л. ГІС-аналіз умов міграції техногенних забруднювачів в ландшафтах Волинського Полісся. Науковий вісник Волинського 
державного університету імені Лесі Украӥнки. Серія «Географічні науки». 2007. № 11. Ч. II. С. 100-104.

Information about authors:

Zubkovych I. V.,

Postgraduate at the Department of Ecology, Geography and Tourism

Rivne State University of Humanities

12, Stepana Bandery str., Rivne, 33028, Ukraine

Martyniuk V. O.,

Candidate of Geographical Sciences, Associate Professor, Professor at the Department of Ecology, Geography and Tourism

Rivne State University of Humanities

12, Stepana Bandery str., Rivne, 33028, Ukraine 